\title{
Editorial
}

\section{Anos da Abem}

\section{Years of Abem}

José Roberto Ferreira

O início da década de 1960 representou um período de grande mobilização no âmbito do ensino superior em geral e da educação médica em particular, tanto na América Latina, como, especialmente, no Brasil. Nessa época, frente a uma crescente demanda de candidatos às universidades, houve uma significativa ampliação da oferta e, paralelamente, maior preocupação com o aperfeiçoamento desse setor, de fundamental importância para o desenvolvimento.

Naquela oportunidade, a tradicional Universidade do Brasil desencadeou um processo de reforma, que resultou na reorientação programática e na mudança de seu nome para Universidade Federal do Rio de Janeiro (UFRJ), com a conotação de que outras instituições semelhantes existiriam nos demais Estados do País.

Na América Latina, no campo da educação médica, foi criada, na mesma época, a Fepafem, seguida do estabelecimento das Associações Nacionais de Ensino Médico — Abem, no caso do Brasil, criada em 1962 - , baseadas no modelo norte-americano, a fim de promover maior avanço desse campo em toda a América.

O Governo brasileiro acompanhou esses avanços. Com a participação dos protagonistas que promoveram as iniciativas referidas acima, o Ministério da Educação (MEC) estabeleceu a Comissão de Planejamento da Formação Médica (CPFM), que se transformou num mecanismo de apoio para reorientar o ensino nessa área e apoiar, juntamente com a Abem, o processo de expansão da rede de escolas em todo o País. Nesse contexto, destaco os principais líderes dessa articulação: Oscar Versiani Caldeira (primeiro Presidente da Abem), Durmeval Trigueiro Mendes (Diretor de Ensino Superior do MEC), Ernani Braga (Diretor Executivo da Fepafem) e Paulo de Goes (da UFRJ). Por decisão desse grupo, me coube assumir, concomitantemente, a Direção Executiva da CPFM e da Abem, o que contribuiu para a coordenação almejada.

É surpreendente a extensa série de debates e iniciativas desenvolvidos nesse campo, nos quais intercederam igualmente a OMS, Opas e fundações estrangeiras, superando em número e amplitude os esforços despendidos em qualquer outra das profissões liberais. A Abem atuou diretamente na promoção e orientação da expansão da rede de escolas, assim como no desenvolvimento dos programas existentes, incluindo a consideração desse processo no âmbito da realidade socioeconômica brasileira, sobretudo em função do mercado de trabalho e da demanda do Sistema Nacional de Saúde. Promoveu ainda análises continuadas das principais questões relativas ao aperfeiçoamento da formação, incluindo a incorporação da medicina preventiva e formação do médico de família, a integração das ciências básicas, a utilização dos cenários de prática, as transformações introduzidas pelo desenvolvimento científico e tecnológico, a avaliação da qualidade da formação e muitos outros aspectos que vêm influenciando o melhoramento dessas atividades. 
Nesse contexto, a Abem promoveu a realização de 48 congressos de educação médica, abordando uma extensa e variada temática, sempre orientada ao aperfeiçoamento do padrão educacional nessa área, incluindo o desenvolvimento pedagógico, a melhor capacitação dos docentes, a promoção da pesquisa clínica e as condições necessárias à preparação prática orientada à promoção e proteção da saúde e ao cuidado médico básico e especializado, procurando adotar um plano de estudos ajustado à situação socioeconômica, ambiental e sanitária prevalente.

Entre as iniciativas de maior destaque se inclui a criação da Cinaem, reunindo entidades representativas da comunidade acadêmica e da classe médica para avaliar os componentes de qualidade do ensino médico no País. Em etapas subsequentes, essa entidade analisou critérios de desempenho das escolas, explorando novos métodos e instrumentos de avaliação em oficinas de trabalho com representantes de alunos e professores. Mais recentemente, vem tratando da construção das transformações necessárias à boa qualidade do ensino médico.

Com a Abem interatuando com as mais variadas iniciativas, como o Preps, Pias, Prev-Saúde, Peses e, mais recentemente, o Promed, Pró-Saúde, PET-Saúde e a UNA-SUS, vêm se desenvolvendo propostas para formar um médico geral e indiferenciado, com a promoção da integração docente-assistencial (IDA). Mais recentemente, a consideração dos determinantes sociais da saúde e uma integração multidisciplinar mais ampla, com a articulação das escolas do setor saúde com os cenários de prática e maior ênfase no autoaprendizado, têm constituído a prioridade da Abem, em articulação com as iniciativas dos ministérios da Saúde e da Educação nesse campo.
Em todas estas promoções, tem sido possível registrar a apropriação por parte das escolas afiliadas, com resultados positivos quanto à reorientação do processo formativo, embora ainda se observem resistências e sérias limitações para maior incorporação dessas mudanças - vistas por alguns como oposição às tendências do mercado de trabalho. $\mathrm{O}$ acompanhamento da implementação dessas mudanças tem evidenciado avanços positivos, mas falta uma adequada avaliação do desempenho dos futuros profissionais após passarem por toda a reorientação referida, incluindo a observação da receptividade e aceitação da população-alvo de seus cuidados, o que permitiria a defesa irrefutável de todas estas propostas.

Aproveitamos esta oportunidade de um marco temporal significativo - como a comemoração de meio centenário da Associação - para, ao destacar a trajetória cumprida e cumprimentar os 22 Presidentes que a conduziram com tantas realizações, sugerir a promoção de um movimento de conscientização acerca desta problemática, com o envolvimento de todas as escolas, das comunidades docentes, discentes e dos próprios serviços de saúde em cada localidade para analisar os fatores que favorecem ou dificultam a adoção de orientações que visam, por meio da formação profissional, a uma real melhoria do sistema de atenção à saúde.

Cumprimento igualmente todas as 197 escolas do País, desejando que nos anos vindouros possam seguir a trajetória vitoriosa cumprida até agora, incluindo o contínuo aperfeiçoamento institucional e contribuindo para termos uma população mais saudável e um Brasil mais desenvolvido. 